\title{
Tiga Tantangan Guru Masa Depan Sekolah Dasar Inklusif
}

\author{
${ }^{1}$ Heri Setiawan, ${ }^{2}$ Styo M. W Aji, ${ }^{3}$ Abdul Aziz \\ ${ }^{1}$ PGSD FKIP Universitas Mataram, Indonesia \\ ${ }^{2}$ Mahasiswa Pascasarjana Universitas Negeri Malang, Indonesia \\ ${ }^{3}$ SDN 2 Polehan Kota Malang, Indonesia
}

Email: ${ }^{1}$ heri_setiawan@uram.ac.id, ${ }^{2}$ styo.mahendra.1621038@students.um.ac.id,

3 aziz.ardath@gmail.com

\begin{tabular}{l} 
Tersedia Online di \\
\hline http://www.jurnal.unublitar.ac.id/i \\
ndex.php/briliant
\end{tabular}

Diterima pada 16 April 2020

Dipublikasikan pada 30 Mei 2020

Hal. 241-251

\begin{tabular}{l}
\hline Kata Kunci: \\
\hline Tantangan; guru SD; inklusif \\
\hline
\end{tabular}

\section{DOI:}

http://dx.doi.org/10.28926/briliant. v3i4.458
Sejarah Artikel

Disetujui pada 29 April 2020

\begin{abstract}
Abstrak: Setiap warga negara memiliki hak yang sama dalam mengenyam pendidikan, termasuk siswa dengan kebutuhan khusus. Salah satu strategi yang dilakukan pemerintah untuk memberikan layanan pendidikan yang layak kepada semua warganya yaitu melalui implementasi pendidikan inklusif pada semua jenjang pendidikan. Dilapangan, guru merupakan ujung tombak dalam pelaksanaan kebijakan pendidikan inklusif. Metode penulisan artikel ini menggunakan kajian pustaka (literature review). Hasil kajian literatur yang dilakukan merumuskan hasil bahwa guru SD inklusif di masadepan dengan segala kompetensi dan sumber daya yang ada ditantang untuk secara riil memahami karakteristik siswa yang terus berubah seiring laju perkembangan zaman; mampu beradaptasi dan berinovasi melalui kegiatan penelitian sebagai tugas wajib selain mengajar; serta mampu
\end{abstract} memaksimalkan learning community yang sudah tersedia melalui KKG maupun wadah komunikasi lain agar dapat menjadi guru SD inklusif yang profesional.

\section{PENDAHULUAN}

Guru merupakan bagian integral dalam dunia pendidikan. Peran guru sebagai garda terdepan dunia pendidikan. Berhasil atau tidaknya programprogram pendidikan juga tergantung dengan guru. Ibarat sebuah orkestra di dalam kelas, guru berperan sebagai komposer. Keberagaman yang ada di kelas merupakan modal untuk menghasilkan simfoni yang indah. Kaitannya dalam pembelajaran seluruh subyek pembelajar di dalam saling mengisi menghasilkan pembelajaran yang baik.

Pada pelaksanaan pendidikan, berbagai tantangan kini dihadapi oleh guru. Guru harus selalu siap dengan setiap inovasi yang masuk di sekolahnya. Dewasa ini pemerintah Republik Indonesia menggalakan pendidikan Inklusif. Kebijakan ini dibuat agar seluruh anak bangsa mendapat kesempatan yang sama untuk memperoleh pendidikan sesuai amanat dalam pembukaan UUD 1945 yaitu mencerdaskan kehidupan bangsa. Hal ini semakin diperjelas dalam batang tubuh UUD 1945 pasal 31 ayat 1 yang menyatakan bahwa, "Setiap warga negara berhak mendapatkan pendidikan". Hal ini tentu menegaskan bahwa tidak ada pengecualian terhadap semua warga negara Indonesia untuk memperoleh pendidikan yang layak. Termasuk anak dengan kebutuhan khusus yang selama ini 
masih mengalami banyak kendala dalam berpartisipasi dan memperoleh akses pendidikan yang layak.

Pendidikan inklusif memiliki beberapa definisi. Khan et al (2017) menyatakan bahwa pendidikan inklusif merupakan sebuah sistem pendidikan yang mengakomodir kebutuhan belajar bagi semua anak dengan berbagai karkteristik termasuk anak dengan kebutuhan khusus. Pendidikan inklusif terkait dengan kewajiban semua pihak untuk menyediakan sebuah layanan pendidikan yang berkualitas bagi semua anak termasuk anak dengan kebutuhan khusus (ABK) di sekolah umum/reguler (Khan et al, 2012). Hal ini menegaskan bahwa dalam pelaksanaannya, pendidikan inklusif merupakan sebuah sistem pendidikan yang menempatkan anak $\mathrm{ABK}$ di dalam kelas reguler bersama anak lain. Pelaksanaan pendidikan inklusif juga harus mengedepankan pelayanan yang berkualitas, dengan pembelajaran dan pelayanan yang sesuai dengan karkteristik dan kebutuhan semua anak yang ada di dalammya.

Pendidikan inklusif merupakan cara pandang baru dalam pelaksanaan pendidikan di Indonesia. Pelaksanaan pendidikan inklusif tidak hanya merubah cara pandang mengajar segregatif tradisional (pengkhususan/ pemisahan anak) berdasarkan kekhususan atau hambatan yang dialami anak (Abbas et al, 2016). Lebih jauh, implementasi pendidikan inklusif diarahkan juga untuk merubah cara pandang masyarakat terhadap keberadaan anak dengan kebutuhan khsusus (ABK). Selama ini, masyarakat utamanya orang tua masih menganggap negatif keberadaan siswa dengan kebutuhan khusus (ABK) sehingga kurang meperhatikan pendidikan anaknya. Hasil penelitian Tarnoto (2016) memperlihatkan bahwa salah satu faktor hambatan dalam implementasi pendidikan inklusi terkait dengan orang tua dan masyarakat. Orang tua anak dan masyrakat kebanyakan belum peduli, cenderung mengabaikan, kurang sabar dalam menangani anaknya, bahkan terdapat kasus orang tua malu dengan kekhususan anaknya.

Sebagai sebuah sistem, pendidikan inklusif memiliki beberapa dampak positif. Pertama, hak anak untuk memperoleh pendidikan yang layak terpenuhi. Kedua, melalui pendidikan inklusif semua anak memperoleh peluang berkembang sesuai dengan potensi dan kebutuhannya. Hal ini diperkuat dengan hasil penelitian Sadioğlu et al (2013) yang menunjukkan bahwa anak ABK yang belajar dalam satu kelas dengan siswa reguler cenderung mengalami perkembangan dan perubahan yang cukup signifikan. Hal ini menunjukkan bahwa pendidikan inklusif, jika dilaksanakan dengan maksimal dapat mengembangkan kemampuan dan potensi siswa baik siswa ABK maupun siswa lainnya.

Pelaksanaan pendidikan inklusif membutuhkan support system yang kuat dan saling mendukung. Support system yang dibutuhkan bukan hanya dukungan dana dan sumber daya dari pemerintah, namun juga keterlibatan semua pihak dan stakeholder terkait. Adapun seluruh pihak yang dimaksud yaitu sekolah (kurikulum, sarana prasarana yang mendukung), guru, siswa, orangtua, dan masyarakat (Tarnoto, 2016).

Guru memiliki peran central dalam implementasi pendidikan inklusif. Guru merupakan garda terdepan sebagai pihak yang melaksanakan pembelajaran di kelas. Selain itu, guru di sekolah inklusif merupakan guru yang istimewa karena tidak hanya sekedar membelajarkan siswa pada umumnya. Mereka juga membelajarkan siswa berkebutuhan khusus, dan siswa yang memiliki 
keistimewaan potensi di dalam dirinya. Peran guru semakin strategis dalam mengelola keragaman yang ada di dalam kelas.

Peran strategis guru inilah yang mendorong penulis untuk berupaya merumuskan tantangan-tantangan bagi guru di sekolah inkusi. Setidaknya ada tiga tantangan yaitu keberagaman karakteristik siswa, guru sebagai peneliti dan komunitas saling belajar guru. Dengan tiga tantangan ini diharapkan menjadi bahan perenungan guru sekolah inklusif untuk dapat mengembangkan pembelajaran yang berkesinambungan yang menghasilkan sebuah simphoni. Mengingat peran strategis guru sekolah inklusif sebagai konduktor dalam orkestra pembelajaran. Dimana pemainnya lebih beragam dibanding dengan pemain orkestra-orkestra pada umumnya.

\section{METODE}

Metode penulisan artikel ini menggunakan kajian pustaka (literature review). Berbagai literatur yang berkaitan dengan topik pembahasan yaitu pendidikan inklusi, peran guru SD dalam pendidikan inklusi, dan berbagai tantangan masa depan guru dalam pelaksanaan pendidikan inklusi di samma depan. Langkah ini dilaksanakan untuk meninjau kurikulum, dasar hukum, serta literatur hasil penelitian dari berbagai sumber seperti Scopus, ERIC, google scholar lalu dianalisis dan disintesis sehingga dapat diambil sebuah kajian yang merumuskan tiga tantangan masa depan bagi guru SD inklusif yaitu pemahaman tentang karakteristik siswa, peran guru sebagai peneliti, serta penguatan dan pembentukan komunitas belajar guru.

\section{PEMBAHASAN}

Implementasi pendidikan inklusif di Indonesia secara lansung menempatkan guru SD sebagai ujung tombak pelaksana di sekolah. Menilik hal ini, profesionalitas dan kompetensi guru SD menjadi aspek yang penting sebagai modal guru untuk menerapkan pendidikan inklusif. Guru SD menurut UndangUndang Nomor 14 Tahun 2005 tentang Guru dan Dosen pasal (1) harus menguasai empat kompetensi meliputi kompetensi pedagogik, kompetensi kepribadian, kompetensi sosial, dan kompetensi profesional. Kompetensi pedagogik adalah kemampuan mengelola pembelajaran siswa. Kompetensi kepribadian adalah kemampuan kepribadian yang mantap, berakhlak mulia, arif, dan berwibawa serta menjadi teladan siswa. Kompetensi profesional adalah kemampuan penguasaan materi pelajaran secara luas dan mendalam.

Selain itu, guna mempersiapkan dan menyongsong generasi Indonesia Emas tahun 2045 guru setidaknya harus mampu memastikan siswanya agar mampu menguasai keterampilan Abad 21. Adapun 4 keterampilan tersebut menurut Kemdikbud (2018) yaitu keterampilan berpikir kritis dan memecahkan masalah (critical thinking and problem solving skills), bekerjasama (collaboration skills), kemampuan untuk berkreativitas (creativities skills), dan kemampuan untuk berkomunikasi (commnication skills). Hal ini juga berlaku bagi guru SD inklusif, agar siswa ABK yang diajarnya mampu berkembang dan menguasai keterampilan 4C dengan berbagai kekhususan dan potensi yang dimiliki oleh siswa tersebut.

Berdasar tuntutan kompetensi dan perkembangan ilmu pengetahuan diatas maka dirumuskan beberapa tantanagn bagi guru SD inklusif dalam melaksanakan 
tugasnya saat ini dan masa yang akan datang. Tiga tantangan ini merupakan tatangan yang urgent, dan harus dipersiapkan oleh guru di SD inklusif agar tidak hanya mampu menyukseskan implementasi pendidikan inklusif, namun juga memastikan kualitas output dan outcome yang dihasikan oleh pendidikan inklusif. Adapun tantangan tersebut yaitu (1) tantangan tentang keberagaman karaktersitik siswa; (2) tantangan dalam menjalankan peran guru sebagai peneliti; dan (3) tantangan bagi guru untuk menguatkan serta membentuk komunitas belajar profesioal bagi guru SD inklusif.

\section{Keberagaman Karakteristik Siswa}

Keberagaman karakteristik siswa berkaitan erat dengan kondisi belajar yang akan disediakan di kelas-kelas sekolah inklusif. Karakteristiik siswa perlu diketahui untuk mengakomodasi keberagaman karakteristik siswa yang khas. Siswa pada sekolah dasar inklusif setidaknya dapat dikelompokkan menjadi 3 kelompok. Pertama, siswa pada umumnya, kedua siswa yang memiliki kebutuhan kelainan khusus, dan ketiga siswa yang memiliki keistimewaan berupa potensi khusus.

Kelompok siswa pada umumnya merupakan siswa-siswa yang tumbuh dan bekembang normal seperti pada umumnya. Siswa yang tumbuh normal ini idealnya telah dapat teridentifikasi oleh guru. Guru idealnya memberikan pelayanan normal bagi siswa-siswa yang seperti ini. Siswa normal di Sekolah Dasar ciri seperti berada ditahap perkembangan kognitif operasional kongkrit. Dimana dalam belajar membutuhkan artefak-artefak yang membantunya untuk memahami konsep dalam belajar.

Tantangan menarik bagi dari segi perkembangan afektif siswa berkembang normal sekolah dasar. Siswa sekolah dasar merupakan puncak dari penanaman nilai-nilai bagi siswa. Nilai yang ditanamkan membekas sampai perkembangan sampai dewasa. Siswa berkembang normal disekolah inklusif perlu ditanamkan nilai menerima perbedaan karakteristik. Melalui hal ini, pembelajaran diharapkan lebih kondusif dan tidak ada perilaku bullying dari siswa yang berkembang normal.

Kelompok siswa yang kedua yaitu siswa yang memiliki kebutuhan khusus berupa kelainan. Kelainan ini beragam, mulai dari yang fisik dan mental. Tantangan bagi guru sekolah inklusif cukup kompleks dalam kaitannya tentang kelainan ini. Guru dituntut untuk mampu mengidentifikasi kelainan yang dimiliki oleh siswa, sehingga kelak dapat membantunya belajar dengan baik. Ada beragam jenis kebutuhan siswa dengan karakteristik ini, seperti disleksia, disgrafia, diskalkulia, ADHD, tuna laras, autism, gangguan emosi dan perilaku, dan tunadaksa (Santrock, 2012: 323-328). Setiap jenis kebutuhan khusus memiliki karakteristik dan keunikan masing-masing sehingga guru memerlukan cara penanganan dan cara mengajar yang berbeda.

Bagi guru, tantangan bagi siswa berkebutuhan khusus ini tentang bagaimana membangun kepercayaan diri dan kemandirian siswa. Siswa idealnya mendapatkan perhatian khusus, sehingga siswa tidak minder dan tetap memiliki semangat belajar sama dengan siswa yang lainnya. Siswa dengan keterbatasan ini terkadang memiliki potensi lain yang luar biasa istimewa. Dengan mendorong kepercayaan diri ini, diharapkan siswa dapat menemukan apa kelebihan yang dimilikinya sehingga dapat menjadi nilai lebih, dan mengagkat kepercayaan diri dalam hal lain. 
Tantangan lain bagi guru bagi siswa yang berkebutuhan khusus jenis ini yakni memberikan lingkungan belajar bagi siswa. Penyediaan lingkungan belajar idealnya memperhatikan kekurangan fisik ataupun mental yang dialami siswa. Perhatian khusus terhadap lingkungan sekolah ini agar aksesbilitas setiap siswa untuk belajar tidak terganggu (Chamidah, 2010:70). Aksesbilitas terkait dengan bagaimana siswa bisa berinteraksi, berkontribusi, dan memiliki akases yang sama dalam pembelajaran di kelas inklusif. Akses bilitas juga menekankan bagaimana setiap siswa berkebutuhan khusus dapat menjangkau dan memanfaatkan materi, media, sumber belajar, dan terlibat aktif dalam setiap tugas serta kegiatan pembelajaran.

Selanjutnya karakteristik siswa yang memiliki kebutuhan khusus berupa keistimewaan khusus. Siswa yang memiliki karakteristik ini tidak menutup kemungkinan mereka mudah bosan dan selalu mencari perhatian di kelas dengan membuat onar. Siswa istimewa ini memiliki kecepatan belajar dalam hal tertentu yang luar biasa dibandingkan dengan siswa yang lainnya. Oleh karena itu, siswa ini tadi berupaya terus mencari perhatian-perhatian yang bisa mengganggu kondisi pelaksanaan pembelajaran di kelas.

Pada kasus ini, tantangan guru mengidentifikasi karakteristik apa yang menjadi keunggulan siswa tersebut. Guru tidak menutup kemungkinan untuk memberikan tugas-tugas lain yang menantang bagi siswa dengan keistimewaan ini. Siswa juga dapat diajak untuk melaksanakan tutor sebaya. Siswa istimewa ini ditantang agar mampu mengajari siswa lain belajar. Tantangan-tantangan seperti inilah yang dapat memfasilitasi siswa dengan karakteristik belajar istimewa.

Tantangan bagi guru sekolah dasar inklusif masa depan tidak berhenti sampai disini. Pada perkembangan masa kini, banyak ahli yang mulai mengklasifikasikan generasi-generasi dari sebuah era dengan sebutan tertentu dan memiliki karakteristik yang khas. Oleh karena itu, guru perlu mengetahui karakteristik generasi ini dengan harapan dapat mengakomodasi karakteristik kebutuhan belajar dari siswanya.

Siswa sekolah dasar saat ini oleh para ahli digolongkan pada generasi alpha. Generasi ini adalah mereka yang lahir pada tahun 2010-2025. Karakteristik umum siswa dari generasi ini yaitu genarasi yang dianggap paling akarab dengan gawai/ dunia digital dan diklaim paling cerdas dibanding generasi sebelumnya. Selain itu, kharakteristik spesifik dari generasi ini yaitu: suka mengatur, tidak suka berbagi, suka menerobos aturan, hidup yang tidak lepas dari teknologi, dan skills komunikasi mereka tidak baik (Purnama, 2018: 497). Ini merupakan bentuk perubahan karakteristik yang cukup berbeda dibanding dengan generasi sebelumnya. Dimana terdapat dua sisi baik negatif maupun positif yang menyertainya.

Tantangan karakteristik seperti ini juga perlu dipertimbangkan oleh guru sekolah inklusif. Pembelajaran kedepan dengan ceramah nampaknya tidak lagi relevan. Pembelajaran yang lebih kooperatif, saling membutuhkan antar siswa, membuat aturan main bersama, dan akrab dengan media digital nampaknya lebih menarik bagi siswa sekolah inklusif dengan karakteristik beragam. Dengan demikian, karakteristik untuk saling menerima perbedaan menjadi terakomodasi. Siswa dapat lebih fleksibel belajar dan kondisi pembelajaranpun diharapkan lebih efektif, efisien dan menarik. 


\section{Guru sebagai Peneliti}

Pada Undang-undang nomor 14 tahun 2005 tentang guru dan dosen dinyatakan guru perlu memiliki kompetensi profesionalisme. Sebagai seorang profesional guru harus benar-benar memiliki kemampuan untuk menguasi tentang substansi keilmuan. Dimana guru perlu menguasai struktur dan metodologi keilmuan. Oleh karenanya, guru perlu memiliki kecakapan dalam melaksanakan penelitian di sekolah.

Faktanya, banyak guru SD belum melaksanakan kompetensi dalam bidang penelitian sebagai bagian dalam pengembangan diri dan profesionlitas. Hasil penelitian Fahdini et al (2014) menunjukkan bahwa 58\% dari 60 guru SD di Sumendang yang sudah memiliki sertifikat pendidik, masih kurang dalam kemampuan mengembangkan keprofesionalan secara berkelanjutan dengan melakukan tindakan reflektif. Kemampuan yang dimaksud termasuk kemampuan guru dalam melaksanakan penelitian di kelasnya. Fakta ini menunjukkan bahwa peran dan kompetensi guru menjadi peneliti merupakan salah satu tantangan nyata hari ini dan dimasa depan, baik dalam pelaksanaan pendidikan umum maupun pendidikan inklusif.

Menilik peran guru sebagai peneliti, tentu harus dipetakan penelitian seperti apa yang dapat dilakukan oleh guru SD secara umum maupun SD Inklusif. Penelitian yang dapat dilakukan oleh guru yaitu penelitian-penlitian yang bersifat fungsional. Menurut Suyanto \& Jihad (2013:74) penelitian ideal yang dapat dilakukan oleh guru yaitu penelitian tindakan (action research). Kecakapan ini dapat digunakan guru dalam rangka mengumpulkan informasi, menganalisis informasi dengan cermat, sehingga dugaan-dugaan tentang efektifitas, efisiensi dan kemenarikan perencanaan, pelaksanaan, pembelajaran dapat dipertanggungjawabkan kevalidannya.

Pembelajaran dan peningkatan layanan di sekolah inklusif diharapkan membaik mutunya. Penelitian yang dilakukan oleh guru ataupun kepala sekolah berpotensi menjadi sarana untuk memperbaiki kualitas pembelajaran dan layanan inklusif dengan lebih valid. Hasil penelitian dapat menjadi bahan refleksi dan renungan bersama guna menentukkan strategi yang lebih baik, ataupun menentukan strategi baru yang memunginkan digunakan untuk inklusif disekolah. Oleh karena itu hasil penelitian guru disebut dengan praksis (Kinchelo, 2014). Praksis merupakan upaya dimana pelaksanaan pembelajaran dalam implementasi pendidikan inklusif tidak memisahkan antara teori dengna praktiknya. Baik praktik maupun teoritik sama-sama memiliki informasi. Melalui penelitian inilah guru menghubungkan konsep teori pendidikan inklusif dalam bentuk praktisnya, sehingga didapatkan kolaborasi yang lebih kuat dan dapat dipertanggungjawabkan secara ilmiah.

Hasil penelitian umumnya dipublikasikan dalam bentuk karya tulis ilmiah. Hasil publikasi inilah bentuk pengembangan dan penyebarluasan pengetahuan baru yang dilakukan oleh guru berdasar hasil temuan peneilitannya (Kinchelo, 2014). Karya tulis ilmiah ini dapat menjadi bahan rujukan yang digunakan oleh sekolah lain. Mereka dapat memanfaatkan hasil tulisan ilmiah guru ini sebagai bahan diskusi mengenai pembelajaran dan layanan inklusif disekolah yang diteliti. Hasil diskusi kemudian juga dapat digunakan untuk kepentingan-kepentingan lebih lanjut. 
Bagi sekolah yang belum menerapkan layanan inklusif, publikasi ilmiah yang dilakukan oleh guru sekolah lain ini dapat menjadi bahan pertimbangan untuk mulai melaksanakan layanan inklusif. Bagi sekolah yang telah melaksanakan layanan inklusif, penelitian ini juga akan berguna. Sekolah dapat menggunakannya sebagai bahan pertimbangan untuk mengkaji pembelajaran ataupun layanan inklusif yang telah dilaksanakan disekolahnya. Apabila sekolah itu belum pernah menemukan kasus layanan bagi suatu kebutuhan khusus, hasil penelitian guru lain ini tentunya juga dapat menjadi bahan pertimbangan strategi penyelesian jika menemui kasus serupa.

Lebih jauh lagi, hasil penelitian juga bermanfaat bagi pemangku kebijakan. Pelaksanaan pendidikan inklusif di sekolah-sekolah belum tentu selalu mendapat perhatian pemerintah. Setiap kebijakan tentunya memiliki dinamikanya sendiri. Di Indonesia peraturan mengenai pendidikan Inklusif telah diataur dalam peraturan menteri pendidikan nasional nomor 70 tahun 2009. Lebih dari 1 dekade kebijakan ini berjalan, belum ada kebijakan yang lebih terkini mengenai pendidikan inklusif lagi. Berapa banyak sekolah inklusif disetiap kecamatan ataupun kota/ kabupaten yang siap memberikan layanan di seluruh Indonesia juga belum dirilis.

Hasil penelitian fungsional yang dilakukan oleh guru inklusif memberikan bahan evaluasi kebijakan. Pemerintah mendapat hasil kajian yang dapat dipertanggunjawabkan secara ilmiah. Hasil mengenai pelaksanaan pembelajaran ataupun layanan inklusif di sekolah-sekolah inklusif. Hasil penelitian juga dapat digunakan sebagai dasar untuk kebijakan baru pemerintah untuk mendorong tumbuhnya mutu sekolah dasar inklusif baik secara kuantitas dan kualitas.

Guru sebagai peneliti tampaknya menjadi salah satu kunci untuk pengembangan pembelajaran maupun layanan inklusif di sekolah dasar. Kompetensi ini memberikan nilai lebih bagi guru. Tugas ini mendorong perbaikan mutu pendidikan inklusif di sekolah dasar secara berkelanjutan dan dapat dipertanggungajawabkan. Kini guru laiknya perlu mempertimbangkan untuk memiliki kemampuan ini.

\section{Penguatan dan Pembentukan Komunitas Belajar Guru Inklusif}

Komunitas belajar guru merupakan sebuah jaringan taupun wadah yang dapat digunakan oleh guru untuk dapat mengembangkan keprofesiannya secara berkelanjutan. Komunitas atau kelompok belajar ini dapat satu bidang studi, antar bidang studi, antar sekolah maupun antar jenjang sekolah. Guru-guru dapat membuat jaringan secara offline maupun online. Secara offline guru dapat melakukan lokakarya, seminar, diskusi terprogram ataupun pelatihan-pelatihan. Semetara online dapat dilakukan daamkomunitas-komunitas online melalui Whatsapp, facebook, instagram, twitter ataupun media sosial lain.

Ada manfaat sehingga pembentukan komunitas belajar ini penting. Setiap guru memiliki masalah berbeda dalam pembelajaran. Guru dapat saling sharing ataupun saling belajar mengenai alterantif penyelesian dari setiap masalah dalam pembelajaran. Bagi guru di sekolah inklusif manfaat yang didapat tentunya jauh lebih banyak lagi. Selain penanganan masalah pembelajaran, guru-guru di sekolah-sekolah inklusif dapat saing bertukar pikiran mengenai alternatif pemenuhan kebutuhan bagi siswa berkebutuhan khusus. Bagi mereka yang sedang menghadapi siswa berkebutuhan khusus sejenis dapat bertukar pengalaman. Selain itu mereka juga dapat saling bertukar pikiran alternatif layanan 
pembelajaran yang diberikan denga guru yang pernah menangani jenis kebutuhan yang sejenis.

Manfaat lain yang diperoleh mereka akan mendapatkan pengetahuan mengenai beragam kebutuhan khusus. Mereka juga dapat saling bertukar program belajar. Guru-guru juga dapat saling berbagai strategi tentang pembelajaran di kelas-kelas inklusif. Oleh karena itu, komunitas belajar guru memberikan harapan peningkatan mutu pembelajaran di kelas inklusif untuk lebih efektif, efisien dan menyenangkan. Profesionalitas mereka akan semakin meningkat berkat komunitas belajar guru ini. Hal ini sesuai dengan penelitian Affandi et al (2018), yang menyatakan bahwa melalui komunitas belajar professional, guru dapat saling bertukar pendapat, informasi, dan pengetahuan yang berhubungan dengan permasalahan yang ada dikelas yang diajar. Melalui diskusi, sharing, dan juga saling berbagi ini guru juga dapat mengembangkan inovasi-inovasi dan solusi bagi pembelajaran yang beliau laksanakan di kelas.

Dari pemaparan diatas, dirumuskan tantangan ketiga bagi guru SD inklusif masa depan yaitu peguatan dan pembentukan komunitas belajar bagi guru inklusif. Konteks pertama berkaitan dengan pengauatan karena memang sebelumnya disekolah terdapat kelompok/komunitas belajar yaitu melalui Kelompok Kerja Guru (KKG). KKG ada di tingkat gugus atau kecamatan yang terdiri dari beberapa guru dari beberapa sekolah. KKG menurut Kemendiknas (2008) mewadahi kegiatan untuk peningkatan kompetensi profesional guru melalui serangakaian kegiatan rutin seperti : (1) diskusi permasalahan pembelajaran; (2) penyusunan silabus, program semester, dan Rencana Program Pembelajaran; (3) analisis kurikulum; (4) penyusunan instrumen evaluasi pembelajaran; dan (4) pembahasan materi dan pemantapan menghadapi Ujian Nasional.

Namun fungsi dan lingkup pelaksanaan KKG masih terbatas pada area/daerah dimana sekolah itu berada. Selain itu, KKG masih dilaksanakan melalui pertemuan tatap muka (offline), belum secara daring (online). Hambatan pelaksanaan KKG juga diperkuat dengan hasil penelitian Wijayanti (2018) yang menyetakan bahwa pelaksanaan KKG di beberapa daerah masih terhambat oleh: (1) kompetensia anggota KKG; (2) sarana dan prasarana yang belum semua memadai; (3) waktu pelaksanaan dan benturan dengan tanggung jawab lain yang harus dikerjakan oleh guru. Sehingga tantangan pertama terkait penguatan peran KKG sebagai wadah belajar bagi guru.

Inovasi perlu dilakukan dalam pelaksanaan KKG sehingga akan lebih efekti perannya dalam pengembangan kompetensi utamanya guru SD di sekolah inklusif. Tantangan pertama, penguatan KKG melalui kerjasama dengan berbagai organisasi profesional pendidikan maupun LPTK. Kerjasama ini bentuknya dapat berupa seminar, workshop, maupun simposium dengan mendatangkan ahli pendidikan dari organisasi atau LPTK tersebut sebagai narasumber. Guru akan memperoleh manfaat berupa ilmu dang pengalaman sebagai pengembangan kompetensi. Disisi lain organisasi profesional dan LPTK memperoleh jaringan dan media untuk deseminasi ilmu yang dimiliki. Inovasi pertama ini jelas tantangan karena masih belum banyak dilakukan oleh KKg dan guru SD inklusfi di Indonesia.

Tantangan penguatan KKG kedua yaitu pengembangan KKG berbasis online. Selama ini KKG masih dilakukan tatap muka. Waktu, sarana prasarana, 
serta benturan dengan tanggungsjawab lain menjadi kendala tersendiri bagi efektifitas KKG. Dengan perkembangan teknologi yang semakin canggih, guru dituntut untuk mengatasi hambatan jarak dan waktu tersebut secara efetif dan efisien. Berbagai platform online pendidikan baik gratis maupun berbayar tersedia untuk mendukung KKG berbasis online ini seperti Zoom Meeting, Teamlink, Google Meeting, Whatsapp, dll. Melalui media yang tesedia, guru harus mampu memanfaatkan peluang tersebut sebagai wadah pengembangan diri. Tantangan KKG online ini cukup menarik mengingat hasil penelitian Fahdini et al (2014) masih terdapat sekitar $40 \%$ dari 60 guru SD bersertifikat pendidik mengalami kendala dalam mengakses Teknologi dan Informasi guna pengembangan kompetensi dan berkomuniaksi.

Konteks kedua terkait Komunitas Belajar Guru inklusif yaitu pembentukan komunitas yang lebih luas dan menjangkau semua kalangan. Luas disini dimaksudkan dengan jangkauan wilayah dan area kerja komunitas belajar tersebut. Menjangkau semua kalangan disini yang dimaksud yaitu tidak hanya guru SD inklusif saja yang dapat berkontribusi didalam kegiatan yang diadakan oleh komunitas belajar tersebut, namun juga praktisi, peneliti, dan aktivisorganisatoris penggiat inklusi bisa terwadahi didalamnya. Hal ini karena selama ini jangkauan Komunitas Belajar Guru yang sudah ada masih dalam lingkup KKG. Masih jarang komunitas yang menjangkau areal dan keanggotaan yang lebih luas dan fleksibel.

Untuk membuat komunitas belajar guru sekolah iklusif atau yang disebut juga jejaring kerja yang lebih luas dapat dilakukan dengan langkah yang dirumuskan oleh Suyanto \& Jihad (2013:243): (1) Mendata kebutuhan, setiap guru memiliki kelebihan dan kekurangan, sehingga mereka saling membutuhkan, oleh karena itu perlu didata potensi keebihan dan kekurangannya mereka; (2) mengorganisir potensi, setiap guru berkesempatan untuk saling bekerjasama; (3) menemukan guru-guru yang lain yang dinilai dapat membantu meningkatkan kemampuan mutu pembelajaran di kelas inklusifnya ataupun pengembangan layanan dan pembelajaran bagi siswa berkebutuhan khusus yang sejenis; (4) Berkolaborasi dengan sepotensi dan kebutuhan masing-masing pihak, sehingga setiap guru inklusif dalam komunitas belajar ini dapat saling menguntungkan untuk peningkatan mutu inklusif; (5) Mengembangkan usaha saling menguntungkan dengan memegang prinsip kejujuran; (6) kerja sama terus dipelihara secara interaktif oleh seluruh anggota komunitas secara; (9) Membangun keterikatan melalui kesamaan-kesamaan dalam wadah kebersamaan melalui usaha membentuk kelembagaan dengan adanya tata nilai, sarana, wewenang yang disepakati seluruh anggoota dan kesetaraan dalam berbagi aspek kerja dan keuntungan yang diperoleh dari seluruh anggota dalam komunitas.

Melalui pembentukan komunitas belajar guru memiliki potensi untuk meningkatkan mutu pendidikan inklusif. Guru-guru di sekolah inklusif perlu mempertimbangkan untuk membangun komunitas belajar ini. Di era digital seperti ini sangat memungkinkan pembentukan komunitas di dunia maya. Jejaring komunitas yang dibentuk memungkinkan dapat lebih luas. Era ini merupakan era kolaborasi untuk mencapai sebuah perbaikan mutu. Guru inklusif sudah selayaknya untuk saling belajar dalam wadah komunitas belajar guru inklusif yang dapat mengakomodasi penyelesaian-penyelesaian masalah pembelajaran 
inklusif dan perbaikan mutu pembelajara inklusif menjadi lebih efektif, efisien dan menarik.

\section{KESIMPULAN}

Berdasarkan kajian yang dipaparkan di atas, dapat ditarik beberapa kesimpulan, yaitu: (1) Guru inklusif masa depan idealnya memahami keberagaman karakteristik siswa dan mencari literature dari ahli mengenai karakteristik siswa terkini sesuai penggolongan yang telah dilakukan ahli; (2) Guru inklusif masa depan idelanya menjadi seorang peneliti yang bisa mendiagnosa dan menganalisis secara cermat masalah dan strategi pembelajaran di kelas yang memiliki siswa berkebutuhan khusus sesuai kebutuhannya yang dapat dipertanggungjawabkan secara ilmiah (valid); (3) Guru inklusif masa depan menguatkan komunitas belajar yang telah ada dan dapat membentuk komunitas belajar guru baru yang lebih luas jangkauan jejaringnya untuk dapat saling menyelesaikan masalah-masalah pembelajaran di kelas-kelas inklusif secara umum dan layanan pembelajaran khusus bagi siswa berkebutuhan khusus, sehingga setiap siswa mendapatkan haknya dalam belajar.

\section{SARAN}

Guru sekolah dasar inklusif masa depan diharapkan dapat mengembangkan diri, terus beraktualisasi demi menyongsong perkembangan pendidikan yang semakin maju. Utamanya dalam tiga analisis kajian tantangan masa depan ini, guru dengan segala kompetensi dan sumber daya yang ada ditantang untuk secara riil memahami karakteristik siswa yang terus berubah seiring laju perkembangan zaman; mampu beradaptasi dan berinovasi melalui kegiatan penelitian sebagai tugas wajib selain mengajar; serta mampu memaksimalkan learning community yang sudah tersedia melalui KKG maupun wadah komunikasi lain agar dapat menjadi guru SD inklusif yang profesional.

\section{DAFTAR RUJUKAN}

Abbas, F., Zafar, A., Naz, T. 2016. Footstep towards Inclusive Education. Journal of Education and Practice. 7 (10), p.48-52.

Affandi, L.H., Ermiada, I., \& Makki, M. 2018. Effective Professional Learning Community Model for Improving Elementary School Teachers' Performance. Advances in Social Science, Education and Humanities Research, volume 326, doi: https://doi.org/10.2991/iccie18.2019.54/estp.20133.1546.

Chamidah, A. N. 2010. Pendidikan Inklusiff untuk Anak Berkebutuhan Khusus. Jurnal Pendidikan Khusus. Vol 7 (2), (online), (https://journal.uny.ac.id/), diakses 9 Februari 2020.

Fahdini, R., Mulyadi, E., Suhandani, D., \& Julia. 2014. Identifikasi Kompetensi Guru Sebagai Cerminan Profesionalisme Tenaga Pendidik Di Kabupaten Sumedang. Mimbar Sekolah Dasar, 1 (1) p. 33-42. (online), (https://ejournal.upi.edu/index.php/mimbar/article/download/874/608), diakses 26 April 2020.

Khan, I. K., Hashmi, S. H., \& Khanum, N. 2017. Inclusive Education in Government Primary Schools: Teacher Perceptions. Journal of Education and Educational Development. 4 (1), p. 32-47. 
Khan, I. K., Ahmed, L., \& Ghaznavi, A. 2012. Child friendly inclusive education in Pakistan. Insight Plus, 5, p.18-20.

Kemendikbud. 2018. Modul Pelatihan Kurikulum 2013 Sekolah Dasar/Madrasah Ibtidaiyah (SD/MI). Jakarta: Dirjen Dikdasmen KEMENDIKBUD.

Kemendiknas. 2008. Standar Pengembangan Kelompok Kerja Guru (KKG) Musyawarah Guru Mata Pelajaran (MGMP). Jakarta: Jakarta: Dirjen Dikdasmen DEPDIKNAS.

Kinchelo, J. L. 2014. Guru Sebagai Peneliti: Pemberdayaan Mutu guru dengan Metode Panduan Penelitian Kualitatif. M. Yasin Yusuf (Ed). Jogjakarta: IRCiSoD.

Peraturan Mendiknas Nomor 70 tahun 2009 tentang Pendidikan Inklusif bagi Peserta Didik Yang Memiliki Kelainan dan Memiliki Potensi Kecerdasan dan/atau Bakat Istimewa.

Purnama, Sidik. 2018. Pengasuhan Digital untuk Genarasi Alpha. Al Hikmah Proceedings on Islamic Early Childhood Education. Vol 1, (online), (https://s3.amazonaws.com/academia.edu.documents/57365843/Pengasu han_Digital_48_Sigit_Purnama_493-502.pdf), diakses 9 Februari 2020

Sadioglu, O. Batu, S. Bilgin, A dan Oksal, A. 2013. Problem, Expectations, and Suggestion of Elementary Teacher Regarding Inclusion. Educational Science: Theory \& Practice. 13 (3), p.1760-1765 DOI: 10.12738.

Santrock, J.W. 2012. Life Spant Development. Jakarta: Penerbit Erlangga

Suyanto \& Jihad, A. 2013. Menjadi Guru Profesional. Jakarta: Esensi

Tarnoto, N. 2016. Permasalahan-Permasalahan yang Dihadapi Sekolah Penyelenggara Pendidikan Inklusi pada Tingkat SD. Humanitas, 13 (1) p. 50-61.(online), (http://digilib.mercubuana.ac.id/manager/t!@file_artikel_ abstrak/Isi_Artikel_626984286959.pdf), diakses pada tanggal 20 Maret 2020.

Undang-undang Dasar Negara Republik Indonesia Tahun 1945.

Undang-undang Nomor 14 tahun 2005 tentang guru dan Dosen.

Wijayanti, R. A. 2018. Pengembangan Kompetensi Profesional Guru Melalui KKG (Kelompok Kerja Guru) di SDN 02 Genengan. Artikel Skripsi. (online),(http://eprints.ums.ac.id/63268/11/NASKAH\%20PUBLIKASI\% 20new.pdf), diakses tanggal 29 April 2020. 